\title{
MODERN POSSIBILITIES OF PRETERM BIRTH PREDICTION
}

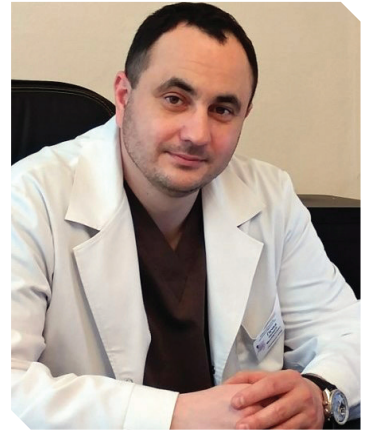

N.M. HYCHKA

$\mathrm{PhD}$, associate professor, Obstetrics and Gynecology Department No. 3, Bogomolets National Medical University, Kyiv

ORCID: 000-0001-9863-6207

V.O. BENYUK

$M D$, professor, head of the Obstetrics and Gynecology Department №. 3,

Bogomolets National Medical

University, Kyiv

ORCID: 0000-0002-5984-3307

V.M. GONCHARENKO

$M D$, professor, Obstetrics and

Gynecology Department No. 3,

Bogomolets National Medical

University, Kyiv

ORCID: 0000-0002-8317-3737

O.A. DYNDAR

$M D$, professor, Obstetrics and Gynecology Department No. 3,

Bogomolets National Medical

University, Kyiv

ORCID: 0000-0002-0440-0410

V.F. OLESHKO

PhD, assistant, Obstetrics and

Gynecology Department No. 3,

Bogomolets National Medical

University, Kyiv

ORCID: 0000-0003-2493-2892

Contacts:

Viktor F. Oleshko

Obstetrics and Gynecology

Department No. 3, Bogomolets

National Medical University

Kyiv City Maternity Hospital No. 3

$7 \mathrm{~V}$. Kuchera str.

03148 Kyiv, Ukraine

Tel.: +38 (099) 0431650

email: docolv@gmail.com

\section{INTRODUCTION}

Premature birth is one of the most important problems in maternal and child health, as it directly affects perinatal morbidity and perinatal mortality. All over the world, somatic illness, menstrual cycle violations, especially at puberty, introduction of assisted reproductive technologies and increase in the number of multiple pregnancies raise the premature birth rate $[3$, $4,8,12,20]$. The highest percentage of preterm births occurs at 34-37 weeks of pregnancy; while at 22-27 weeks the rate of preterm birth is 12 times lower $[2,4,24]$.

High incidence of premature newborns is an economic problem for health care. This is due to the high cost of premature newborns nursing. However, even the highest quality treatment and nursing do not always save premature newborns, especially those born with extremely low body weight, from the prospect of disability (psychomotor development disorders, blindness, cerebral disorders, deafness and chronic lung diseases) $[1,9,18]$. Nursing a child weighing less than $750 \mathrm{~g}$ costs $\$ 274000$ in the United States and a child weighing 750-999 g costs $\$ 138000$. In Sweden nursing a child with an extremely low body weight during the period of artificial lung ventilation costs $€ 3000$ per day, and further care before discharge home costs another $€ 40000$ [13].

The stillbirth in measures of premature birth is 8-13 times higher than for timely deliveries. Newborns weighing less than $1500 \mathrm{~g}$ at birth are 200 times more likely to die, and if they survive, they are 10 times more likely to have neurological and somatic complications than newborns weighing more than $2500 \mathrm{~g}$ at birth $[5,11]$. There is no system prepared to an independent postnatal existence at a prematurely born fetus with an extremely low body weight. Respiratory distress syndrome, necrotizing enterocolitis, intraventricular hemorrhages, paraventricular leukomalacia, retinopathy leading to blindness, and heart defects are frequently observed. Newborns that die in the first 7 days of life make up $67 \%$ of all those who died in the first year of life, $80 \%$ of those who did not survive during the first week are premature children $[1,6,9,18,21]$.

At the same time, increased alertness of doctors in the aspect of possible premature deliveries, often leads to unjustified hospitalization in the obstetric hospital of pregnant women after 22 weeks with complaints of aching pain in the lower abdomen or spastic pain, which can be most often caused by impaired intestinal motili- ty. And only in hospital environment, for the purpose of "reinsurance", pregnant women are given a course of tocolytic therapy and prevention of respiratory distress syndrome. The average pharmacological load per pregnant woman is 5-6 medications, most of which are purchased by a pregnant woman herself for her own money. In $60-85 \%$ of pregnant women admitted to an obstetric hospital with a suspicion of threatening premature birth, the diagnosis is not confirmed. The discharge of such pregnant women is made after 7-10 days, this time is quite sufficient for contamination of a pregnant with intra-hospital infection.

Traditionally, antenatal screening for early spontaneous preterm birth is based on the analysis of maternal characteristics such as age, race and smoking. And one of the most important things is the fact of preterm birth in the history. However, the risk assessment system based on these factors, as shown by clinical practice, has a low level of detection and a high frequency of false positive results.

A widely used additional method is a transvaginal ultrasound examination, aimed primarily at measuring the cervix length, allows detecting pregnant women with a risk of upcoming premature birth only in 55\% compared to $38 \%$ when analyzing maternal factors. At the same time, when using a combination of these diagnostic methods, this figure reaches $69 \%$. However, the use of this method often depends on the human factor - the specialist qualification and the equipment he works with. It should be remembered that that the difference in the cervical measurement result in transvaginal and transabdominal ultrasound can reach $1 \mathrm{~cm}$ that is extremely significant $[6,10,14,18]$.

Today, the method of fetal fibronectin detecting in the vaginal discharge and cervical mucus is widely used in the world practice. The fetal fibronectin is a high-molecular weight glycoprotein $(45 \mathrm{kDa})$ that is normally produced by chorion cells and serves as an extracellular material that participates in the process of attaching fetal membranes to the decidual membrane of the uterine cavity. Cleavage by enzymes of degradation of the extracellular matrix and macromolecular components of fibronectin is one of the components of the delivery process $[16,17,19$, $22,25]$. These proteins can be detected when they enter the cervical mucus and vaginal contents and indicate "activation of the fetal membranes". Increased concentration of fibronectin in vaginal secretions will be typical for pregnant 
women with both timely and premature deliveries. The sensitivity of this indicator is the highest in a case of preterm labor developing in the next 7 to 14 days $(67 \%$ and $71 \%$, respectively) and is less significant in a case of preterm labor onset predicting within 21 days (59\%) [15, 16, 19, 21, 23]. Performing this analysis does not cause difficulties and this technique can be used both by an obstetrician-gynecologist and a general practitioner at the outpatient stage.

Purpose of the study is to improve the method of preterm deliveries onset predicting in pregnant women at 24-34 weeks.

\section{MATERIALS AND METHODS}

49 pregnant women with gestational age 24-34 weeks who were hospitalized in the Pathologic Pregnancy Department of the Kiev City Maternity Hospital No. 3 with a diagnosis of "threatening premature deliveries" were comprehensively examined. The average age of examined women ranged from 26-34 years and averaged out 31,2 $\pm 0,6$ years. Criteria for inclusion of pregnant women in the survey were: the gestational age of 24-34 weeks, the first pregnancy, absence of regular labor at the time of hospitalization.

In addition to the routine examination, regulated by the Order of the Ministry of Health of Ukraine No. 624, in order to diagnose the condition of the cervix, all women at the first stage of the survey had a complex transvaginal ultrasound. During the ultrasound examination the ratio of the cervix length to its diameter at the level of internal orifice (the value of the coefficient less than 1.53 was considered as clinically significant) was calculated, the percentage of the width of the deformation to the length of the cervix was calculated in the case of $Y-, V$ - or $\mathrm{U}$ - like deformation presence of (the value exceeding $40 \%$ was considered as clinically significant), Valsalva's cough test and the presence of dilated veins in the venous plexuses of the cervix was determined by color Doppler mapping [7].

Subsequently, at the second stage of the examination, pregnant women with a shortened cervix $\leq 25 \mathrm{~mm}$ were given a qualitative determination of fetal fibronectin using the "rapid test for fetal fibronectin determining by vaginal secretions". If the quality test for fetal fibronectin was negative, pregnant women were prescribed symptomatic therapy aimed at relieving pain in the lower abdomen. If the result was positive, tocolytic therapy, prevention of respiratory distress syndrome, prolonged support with progesterone and magnesium preparations, vaginal sanitation and obstetric pessary application were prescribed.

\section{STUDY RESULTS}

Diseases of the urinary system in the structure of extragenital pathology of the examined pregnant women were in $19(38.8 \%)$ patients, diseases of the respiratory system in 17 (34.7\%) and the cardiovascular system in 12 (24.5\%).

In the gynecological history the background and precancerous diseases of the cervix were in 20 (40.1\%), inflammatory diseases of the reproductive system in $16(32.6 \%)$ and menstrual disorders in $11(22.4 \%)$ patients. The polycystic ovary syndrome of A phenotype was typical for 8 (16.3\%) pregnant women and caused $8(16.3 \%)$ cases of infertility in examined pregnant women.
Every third patient was complicated by threatening early spontaneous abortion - 15 (30.6\%), placental dysfunction $17(34.7 \%)$, gestosis of the first half of pregnancy $-13(26.5 \%)$, pregnancy anemia of varying severity - $18(36.7 \%)$, every fourth one had abnormal amniotic fluid - $9(18.4 \%)$, every fifth - gestational pyelonephritis - $7(14.2 \%)$, vaginitis $12(24.5 \%)$ and bacterial vaginosis - 6 (12.2\%).

The results of the first stage of examination with complex transvaginal ultrasound revealed the clinically significant structural changes in the cervix only in 21 (42.9\%) pregnant women (Fig. 1).

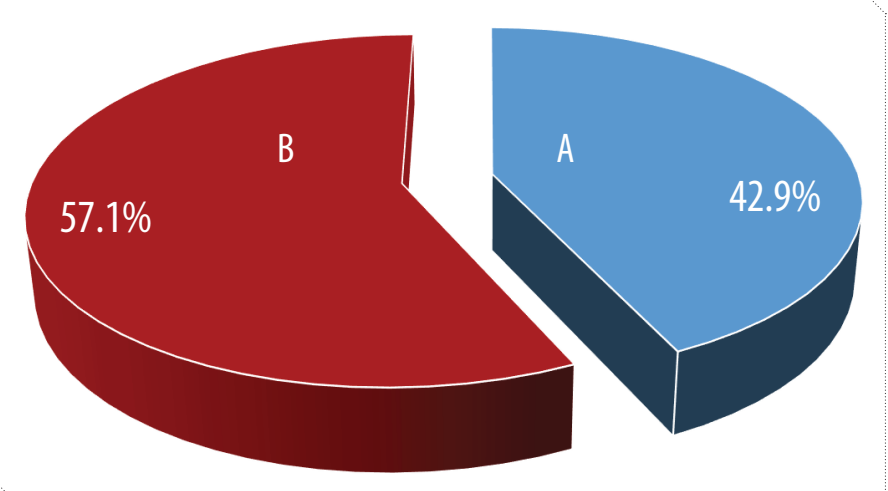

Figure 1. Percentage of women with (A) and without (B) structural cervical changes

The average value of the cervix length varied between 16-24 $\mathrm{mm}$ and averaged $18.2 \pm 0.4 \mathrm{~mm}$. The average value of the cervix length ratio to its diameter at the level of the internal orifice in the examined pregnant women was $1.21 \pm 0.03$. Primary absence of the cervical canal deformity was observed in 11 (52.4\%) pregnant women. 10 (47.6\%) pregnant women were characterized by $Y$ ( 2 pregnant women $-20.0 \%$ ), U (3 pregnant women - 30.0\%) and $\mathrm{V}(5$ pregnant women $-50.0 \%)$ deformities (table).

Table. Primary cervical deformation in women with structural cervical changes, $\mathrm{n}(\%)$

\begin{tabular}{|l|c|}
\hline \multicolumn{1}{|c|}{ Index } & Value \\
\hline$Y$ deformation & $2(20.0)$ \\
\hline$U$ deformation & $3(30.0)$ \\
\hline$V$ deformation & $5(50.0)$ \\
\hline
\end{tabular}

Later during the Valsalva's cough test, the deformation of the cephalic canal by fetal membranes was detected in more 4 (19.0\%) cases: Y-like in 1 pregnant woman (25.0\%), U-like in 1 pregnant woman (25.0\%), and V-like in 2 pregnant women (50.0\%). The presence of dilated veins in the venous plexuses, small liquid inclusions and bright dashed echoes was defined for 9 (42.9\%) pregnant women.

In qualitative determination of the fetal fibronectin in vaginal secretions a positive test was detected in 7 (33.3\%) of 21 pregnant women with clinically significant structural changes in the cervix (Fig. 2).

These pregnant women in addition to correcting concomitant obstetric and extragenital pathology were offered the maximum amount of therapy aimed at prolonging pregnancy. The main prescriptions included micronized progesterone 


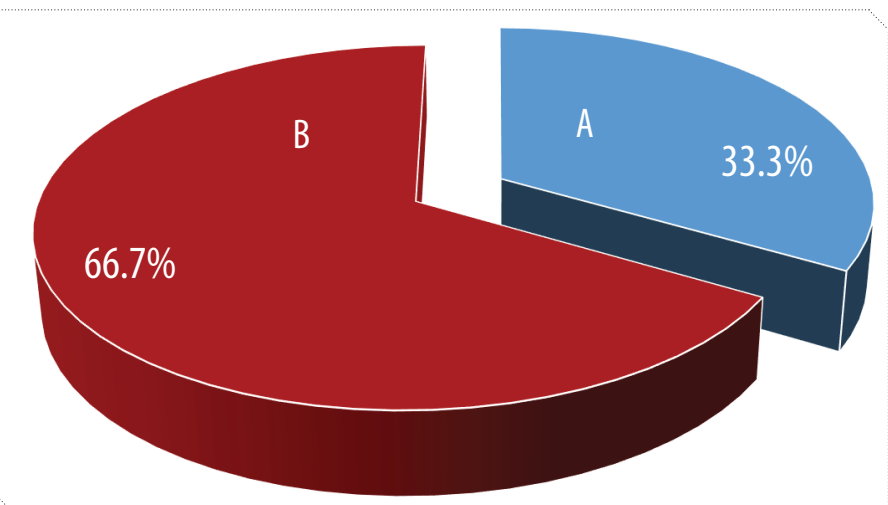

Figure 2. Percentage of women who had positive fetal fibronecine test (A) among women with structural cervical changes

medications, tocolytic therapy, magnesium support, twostage vaginal sanitation with pathogenetically determined local antibacterial drugs, followed by the administration of vaginal probiotic forms and the obstetric pessary application, and a course of glucocorticoids to prevent fetal respiratory distress syndrome.

Despite the ongoing therapy in the dynamics of management during 10 days premature birth occurred in 3 (42.9\%) of 7 pregnant women with clinically significant cervix shortening and a positive test for fetal fibronectin in the gestation period of 32 weeks -2 cases and at 34 weeks -1 case. It should also be noted that cases of premature birth were typical for pregnant women with V-like deformation of the internal orifice and the presence of dilated veins in the venous plexuses, which were manifested by small liquid inclusions and bright dashed echoes during color Doppler mapping.

In $4(57.1 \%)$ of 7 pregnant women therapy aimed at maintaining pregnancy was found to be effective, which contributed to the pregnancy prolongation for a period of more than 36 weeks.

Hospitalization in an obstetric hospital was found to be unjustified in 28 (57.1\%) cases, since no clinical manifestations of threatening premature birth were detected during the extensive examination.

\section{CONCLUSION}

Conclusions of a comprehensive assessment of the cervix state and vaginal fetal fibronectin evaluation in pregnant women with risk of preterm deliveries at the outpatient stage allows to predict the manifestation of preterm birth in critical terms also determine the volume and direction of therapy in obstetric department. Combination of this methods help to prevent unwarranted hospitalization of a pregnant woman in an obstetric hospital. As a result, it limits the conduct of glucocorticoid therapy and prevent a prolong stay of a pregnant woman in a hospital and the associated contamination with nosocomial bacteria strains.

In our opinion it is appropriate to conduct further studies in the chosen direction to establish correlative links between the ultrasound signs of threatening premature deliveries and the presence of fetal fibronectin in the vaginal contents.

\section{ЛITEPATYPA/REFERENCES}

\section{1. Айламазян, Э.К.}

Дискуссионные проблемы преждевременных родов и выхаживания детей с

экстремально низкой массой тела / Э.К. Айламазян // Журнал акушерства и женских болезней. - 2011. - № 9 (3). - С. 183-189.

Ajlamazjan, J.K.

"Debatable problems of premature birth and nursing of children with extremely low body weight". Journal of Obstetrics and Women's Diseases 9.3 (2011): 183-9.

\section{2. Баранов, И.И.}

Медицинские и социальные аспекты преждевременных родов / И.И. Баранов, Ю.П. Скрипниченко, 3.3. Токова, И.Н. Кузьмич // Гинекология. - 2014. - № 5. - С. 90-93. Baranov, I.I., Skripnichenko, Y.P., Tokova, Z.Z., Kuzmich, I.N.

"Medical and social aspects of preterm birth." Gynecology 5 (2014): 90-3.

\section{3. Бенюк, В.0.}

Цитокіновий профіль і імуногістохімічний стан ендометрія жінок із невиношуванням вагітності на тлі надлишкової маси тіла та метаболічного синдрому / В.0. Бенюк, 0.А. Диндар // Імунологія та алергологія: наука і практика. - 2014. -№ 4. -С. 33-7. Beniuk, V.O., Dyndar, O.A.

"Cytokine profile and immunohistochemical state of the endometrium of women with habitual miscarriage on the background of overweight, metabolic syndrome." Immunology and Allergology: Science and Practice 4 (2014): 33-7.

4. Дяк, К.В.

Прогнозування передчасних пологів: реалії і перспективи / К.В. Дяк, 0.М. Юзько // Неонатологія, хірургія та перинатальна медицина. - 2017. - № 4 (26). - С. 87-90. Diak, K.V., Juzko, O.M.

"Predicting preterm birth: realities and prospects." Neonatology, surgery and perinatal medicine $4.26(2017): 87-90$.

\section{5. Жук , C.I.}

Порівняльна характеристика різних методів лабораторної діагностики передчасних пологів / С.І. Жук, І.В. Ус, О.Г. Бикова, Н.В. Пехньо // Здоровье женщины. - 2015. -№ 5 (101). - C. 38-40.

Zhuk, S.I., Us, I.V., Bykova, O.G., Pehnio, N.V.

"Comparative characteristics of various methods of laboratory diagnostics of premature birth." Health ofWomen 5.101 (2015): 38-40.

6. Олексієнко, І.В.

Сучасний погляд на етіологію, діагностику та лікування істміко-цервікальної недостатності шийки матки (огляд літератури) / І.В. Олексієнко, Г.В. Чайка, М.Г.

Заславська, І.Г. Пролигіна // Вісник Вінницького національного медичного університету. 2016. - № 1 (20). - C. 137-140.

Oleksienko, I.V., Chaika, G.V., Zaslavska, M.G., Prolygina, I.V.

"Modern view of the etiology, diagnosis and treatment of cervical isthmic-cervical insufficiency (literature review)."Visnyk Vinnyckogo nacionalnogo medychnogo universytetu 1.20 (2016):

137-140.

7. Патент UA 115797.

Спосіб прогнозування змін стану шийки матки у вагітних з істміко-цервікальною недостатністю. База патентів України: 5 с.

Patent UA 115797.

Method for predicting changes in the state of the cervix in pregnant women with isthmiccervical insufficiency. Ukrainian Patent Database: 5 p.

8. Подзолкова, Н.М.

Нормализация менструального цикла дидрогестероном / Н.М. Подзолкова, Т.Ф. Татарчук, А.М. Дощчанова и др. // Акушерство и Гинекология (Российская Федерация). - 2018. № 6. - C. $70-75$.

Podzolkova, N.M., Tatarchuk, T.F., Doshchanova, A.M., et al.

"Menstrual cycle normalization with dydrogesterone." Akusherstvo i Ginekologiya (Russian Federation) 6 (2018): 70-5.

9. Радзинский, В.Е.

Акушерская агрессия / В.Е. Радзинский. - М.: Изд-во журнала «StatusPraesens», 2011. - 668 с.

Radzinskij, V.E.

Obstetric aggression. Moscow. Publishing house of the "StatusPraesens" Journal (2011): 668 p. 10. Романенко, Т.Г.

Істміко-цервікальна недостатність: діагностика, тактика ведення вагітності, методи корекції (аналітичний огляд літератури) / Т.Г. Романенко, І.П. Мельничук І.П. // Здоровье женщины. - 2014. - № 1. - С. 41-46.

Romanenko, T.G., Melnychuk, I.P.

"Isthmic-cervical insufficiency: diagnostics, pregnancy management tactics, correction methods (analytical literature review)." Health of Women 1 (2014): 41-6.

11. Серов, B.H.

Эффективность профилактики преждевременных родов / В.Н. Серов, О.И. Сухорукова //

Акушерство и гинекология. - 2013. - № 3. - С. 48-53. 


\section{ВАГІТНІСТЬ ТА ПОЛОГИ}

Serov, V.N., Sukhorukova, O.Y

"The effectiveness of the prevention of premature birth." Obstetrics and Gynecology 3 (2013): 48-53.

12. Татарчук, T.

К вопросу об аутоиммунном поражении яичников в период полового созревания / Т. Татарчук, Н. Захаренко,

И. Бачинская, Н. Косей // Грузинские медицинские новости. - 2018. - № 279. -

C. 49-56.

Tatarchuk, T., Zakharenko, N., Bachynska, I., Kosey N.

"On the issue of autoimmune ovary damage during puberty." Georgian medical news 279 (2018): 49-56.

13. Ушакова, Г.А.

О качестве жизни, правах и судьбе человека, родившегося с экстремально низкой массой тела / Г.А. Ушакова //

StatusPraesens. - 2012. - № 3 (9). - C. 11-13.

Ushakova, G.A.

"About the quality of life, rights and fate of a person born with an extremely low body weight." StatusPraesens 3.9 (2012):

$11-3$.

14. Щербина, Н.A.

Исходы беременности при консервативной и хирургической коррекции истмико-цервикальной недостаточности / Н.А. Щербина, Е.И. Скорбач, Муавия Салем Насер Альмарадат, Д.В. Коломацкая // Молодий вчений. - 2014. - № 7 (10). - (. 5-7.
Shcherbina, N.A., Skorbach, E.I., et al.

"Pregnancy outcomes in conservative and surgical correction of isthmic-cervical insufficiency." Molodyj vchenyj 7.10 (2014): $5-7$.

15. Berghella, V., Hayes, E., Visintine, J.

"Fetal fibronectin testing for reducing the risk of preternbirts".

Cochrane Database Syst Rev 4 (2008): 1-8. D0l:

10.1002/14651858.CD006843.pub2

16. Claire, F., Shennan, A.H.

"Fetal fibronectin as a biomarker of preterm labor: a review of the literature and advances in its clinical use." Biomarkers Med 8.4 (2014): 471-84.

17. Deshpande, S.N., van Asselt, A.D.I., Tomini, F., et al.

Rapid fetal fibronectin testing to predict preterm birth in women with symptoms of premature labour: a systematic review and cost analysis. National Institute for Health Research (2013): 161 p. DOl: 10.3310/hta17400

18. Flood, K., Malone, F.D.

"Prevention of preterm birth". Seminars in fetal \& neonatal medicine 17.1 (2011): 58-63.

19. Fuchs, F., Lefevre, C., Senat, M., Fernandez, H.

"Accuracy of fetal fibronectin for the prediction of preterm birth in symptomatic twin pregnancies: a pilot study". Scientific

Reports 8 (2018): 2160.

20. Kiss, H., Petricevic, L., Husslein, P.

"Reducing the rate of preterm birth through a simple antenatal Aspects of Women's Health 6 (2013): 34-9. screen-and-treat programme: a retrospective cohort study." European journal of obstetrics \& gynecology and reproductive biology 153 (2010): 38-42.

21. Leitich, H., Kaider, A.

"Fetal fibronectin - How useful is it in the prediction of preternbirts?"BJOG 110.20 (2003): 66-70.

22. Mazza, E., Parra-Saavedra, M., Bajka, M., et al.

"In vivo assessment of the biomechanical properties of the uterine cervix in pregnancy." Prenatal Diagnosis 34 (2014):

33-41.

23. Michael S. Ruma, Katie C. Bittner, Clara B. Soh.

"Current Perspectives on the Use of Fetal Fibronectin Testing in Preterm Labor Diagnosis and Management." Am I Manag Care 23 (2017): 356-62.

24. Norman, J.E., Marlow, N., Messow, C.M., Shennan, A.

"Vaginal progesterone prophylaxis for preterm birth (the OPPTIMUM study): a multicentre, randomized, double-blind trial."Lancet 387 (2016): 2106-16.

25. Riboni, F., Vitulo, A., Plebani, M.

Биохимические маркеры при прогнозировании преждевременных родов / Ф. Рибони, А. Витуло, М.

Плебани // Медицинские аспекты здоровья женщины. 2013. - № 6. - C. 34-39.

Riboni, F., Vitulo, A., Plebani, M.

"Biochemical markers for predicting preterm birth." Medical

\section{MODERN POSSIBILITIES OF PRETERM BIRTH PREDICTION}

N.M. Hychka, PhD, associate professor, Obstetrics and Gynecology Department No. 3, Bogomolets National Medical University, Kyiv V.O. Benyuk, MD, professor, head of the Obstetrics and Gynecology Department No. 3, Bogomolets National Medical University, Kyiv V.M. Goncharenko, MD, professor, Obstetrics and Gynecology Department №. 3, Bogomolets National Medical University, Kyiv

0.A. Dyndar, MD, professor, Obstetrics and Gynecology Department No. 3, Bogomolets National Medical University, Kyiv

V.F. Oleshko, PhD, assistant, Obstetrics and Gynecology Department No. 3, Bogomolets National Medical University, Kyiv

Purpose of the study is to improve the method of preterm deliveries onset predicting in pregnant women at 24-34 weeks.

Materials and methods. 49 pregnant women with gestational age $24-34$ weeks and with diagnosis of "threatening premature deliveries" were comprehensively examined using transvaginal ultrasound. Pregnant women with a shortened cervix $\leq 25 \mathrm{~mm}$ were given a qual litative determination of fetal fibronectin. The average age of pregnant women ranged from $26-34$ years and averaged out $31.2 \pm 0,6$ years.

Study results. Clinically significant structural changes in the cervix were only in 21 (42.9\%) pregnant women. The average value of the cervix length varied between $16-24 \mathrm{~mm}$ and averaged $18.2 \pm 0.4 \mathrm{~mm}$. Positive test on fetal fibronectin in vaginal secretions was in 7 (33.3\%) of 21 pregnant women with clinically significant structural changes in the cervix. During 10 days premature birth occurred in $3(42.9 \%)$ of 7 pregnant women with clinically significant cervix shortening and a positive test for fetal fibronectin in the gestation period of 32 weeks. Hospitalization in an obstetric hospital was found to be unjustified in 28 (57.1\%) cases.

Conclusions. Combination of a comprehensive assessment of the cervix state and vaginal fetal fibronectin evaluation in pregnant women with risk of preterm deliveries at the outpatient stage allows to predict the manifestation of preterm birth in critical terms also determine the volume and direction of therapy in obstetric department. Combination of this methods help to prevent unwarranted hospitalization of a pregnant woman in an obstetric hospital and as a result it limits the conduct of glucocorticoid therapy and prevent a prolong stay of a pregnant woman in a hospital and the associated contamination with nosocomial bacteria strains.

Keywords: pregnancy, cervical condition, fetal fibronectin, premature deliveries, transvaginal sonography.

\section{СУЧАСНІ МОЖЛИВОСТІ ПРОГНОЗУВАННЯ ПЕРЕДЧАСНИХПОЛОГІВ}

Н.М. Гичка, К. мед. н., доцент кафедри акушерства і гінекології № 3 НмУ ім. 0.0. Богомольця, м. Київ

В.О. Бенюк, Д. мед. Н., професор, завідувач кафедрою акушерства та гінекології № 3 НмУ ім. 0.0. Богомольця, м. Київ

В.М. Гончаренко, д. мед. Н., професор кафедри акушерства і гінекології № 3 НМу ім. 0.0. Богомольця, м. Київ

О.А. Диндар, Д. мед. Н., професор кафедри акушерства і гінекології№ 3 нму ім. 0.0. Богомольця, м. Київ

В.Ф. Олешко, к. мед. н., асистент кафедри акушерства і гінекології № 3 Нму ім. 0.0. Богомольця, м. Київ

Мета дослідження: вдосконалення методики прогнозування настання передчасних пологів у вагітних в терміні 24-34 тижні.

Матеріали і методи. Комплексно обстежено 49 вагітних у терміні гестації 24-34 тижні з діагнозом при госпіталізації «загроза передчасних пологів». 3 метою діагностики стану шийки матки всім вагітним проводилося комплексне трансвагінальне ультразвукове дослідження. Вагітним з укороченням шийки матки $\leq 25$ мм проводилося якісне визначення фетального фібронектину у вагінальному секреті. Середній вік обстежених становив $26-34$ роки і склав у середньому $31,2 \pm 0,6$ року. Результати дослідження. Наявність клінічно значущих структурних змін в шийці матки виявлено тільки в 21 (42,9\%) вагітної. Середнє значення довжини шийки матки коливалося в межах 16-24 мм і в середньому склало 18,2 $\pm 0,4$ мм. Визначення фетального фібронектину виявило позитивний результат у 7 (33,3\%) 321 вагітної з клінічно значущими структурними змінами шийки матки, яким в подальшому був запропонований максимальний обсяг терапії, ппрямованої на пролонгування вагітності. Протягом 10 днів передчасні пологи відбулись у 3 (42,9\%) із 7 вагітних з клінічно значущим укороченням шийки матки і позитивним тестом на фетальний фібронектин в терміні гестації 32 і 34 тижні. У 28 (57,1\%) випадках госпіталізація в акушерський стаціонар виявилася необгрунтованою.

Висновок. Поєднання комплексної оцінки стану шийки матки та визначення фетального фібронектину у вагінальних виділеннях у вагітних групи ризику передчасних пологів на амбулаторному етапі дозволяє прогнозувати маніфестацію передчасних пологів в критичні терміни, визначити обсяг і спрямованість терапії в умовах акушерського стаціонару. Комбіноване використання цих методів допомагає запобігти необгрунтованій госпіталізації вагітної в акушерський стаціонар і, як резупьтат, обмежити провелення глюкокортикоїдної терапії, профілактувати тривале перебування в стаціонарі і пов'язане з цим інфікування внутрішньолікарняною інфекцією.

Ключові слова: вагітність, фетальний фібронектин, передчасні пологи, стан шийки матки, трансвагінальне ультразвукове дослідження.

СОВРЕМЕННЫЕ ВОЗМОЖНОСТИ ПРОГНОЗИРОВАНИЯ ПРЕЖДЕВРЕМЕННЫХ РОДОВ

Н.М. Гычка, к. мед. Н., доцент кафедры акушерства и гинекологии № 3 НмУ им. А.А. Богомольца, г. Киев

В.А. Бенюк, Д. мед. Н., профессор, заведующий кафедрой акушерства и гинекологии № 3 НмУ им. А.А. Богомольца, г. Киев

В.Н. Гончаренко, Д. мед. Н., профессор кафедры акушерства и гинекологии № 3 НМУ им. А.А. Богомольца, г. Киев

Е.А. Дындарь, Д. мед. Н., профессор кафедры акушерства и гинекологии № 3 НмУ им. А.А. Богомольца, г. Киев

В.Ф. Олешко, к. мел. Н. ассистент кафедры акушерства игинекологии № 3 нму им. А.А. Богомольца г. Киев

Цель исследования: усовершенствование методики прогнозирования наступления преждевременных родов у беременных в сроке 24-34 недели.

Материалы и методы. Комплексно обследовано 49 беременных в сроке гестации 24-34 недели с диагнозом при госпитализации «угроза преждевременных родов». С целью диагностики состояния шейки матки всем беременным проводилось комплексное трансвагинальное ультразвуковое исследование. Беременным сукорочением шейки матки $\leq 25$ мм проводилось качественное определение фетального фибронектина в вагинальном секрете. Средний возраст обследованных колебался от 26 до 34 лет и составил в среднем $31,2 \pm 0,6$ года.

Результаты исследования. Наличие клинически значимых структурных изменений в шейке матки выявлено только у 21 (42,9\%) беременной. (реднее значение длины шейки матки колебалось в пределах $16-24$ мм и в среднем составило 18,2 $\pm 0,4$ мм. Определение фетального фибронектина выявило положительный результат у 7 (33,3\%) из 21 беременной с клинически значимыми структурными изменениями шейки матки, которым впоследствии был предложен максимальный объем терапии, направленной на пролонгирование беременности. В течение 10 дней преждевременные роды произошли у 3 (42,9\%) из 7 беременных с клинически значимым укорочением шейки матки и положительным тестом на фетальный фибронектин в сроке гестации 32 и 34 недели. В 28 (57,1\%) случаях госпитализация в акушерский стационар оказалась необоснованной.

Выводы. Сочетание комплексной оценки состояния шейки матки и определение фетального фибронектина в вагинальных выделенияху беременных группы риска по преждевременным родам на амбулаторном этапе позволяет прогнозировать манифестацию преждевременных родов в критические сроки, определить объем и направленность терапии в условиях акушерского стационара. Комбинированное использование этих методов помогает предотвратить необоснованную госпитализацию беременной в акушерский стационар, и, как результат, ограничить проведение глюкокортикоидной терапии, профилактировать длительное пребывание в стационаре и связанное с этим инфицирование внутрибольничной инфекцией.

Ключевые слова: беременность, фетальный фибронектин, преждевременные роды, состояние шейки матки, трансвагинальное ультразвуковое исследование. 